\begin{tabular}{c} 
Volume and Issues Obtainable at Center for Sustainability Research and Consultancy \\
Review of Politics and Public Policy in Emerging Economies \\
ISSN: $2708-3829$ \& (E): 2708-356X \\
Volume 2: No. 2, December 2020 \\
CSRE \\
Journal homepage: $\underline{\text { www.publishing.globalcsrc.org/rope }}$ \\
\hline
\end{tabular}

\title{
The Political Class as a Threat to Democracy in Nigeria's Fourth Republic
}

*Alfa Patrick Innocent, Department of Social Science and Humanities, The Federal Polytechnic, Idah, Kogi State, Nigeria

Otaida Eikojonwa, Department of Political Science, Federal University Dutsin Ma, Katsina State, Nigeria

Isah Ibn-Mohammed, Department of Social Science and Humanities, The Federal Polytechnic, Idah, Kogi State, Nigeria

*Corresponding author's email: alfaintellectual@gmail.com

\begin{tabular}{l} 
ARTICLE DETAILS \\
\hline History \\
Revised format: Nov 2020 \\
Available Online: Dec 2020 \\
\hline
\end{tabular}

Keywords

Political Class, Democracy, Godfatherism, Nigeria, Fourth Republic.

\section{JEL Classification}

$D 72, D 79$ \begin{abstract}
The quest by Nigeria to make appreciable progress in her democratic journey has been a herculean task. This is due the antidemocratic actions of the political class This article aims at identifying how actions of the political class act as a backward clog to democratic growth in the country. Crucial among the causative factors is the fact that its political class decelerates the country's democracy by their abysmal display of undemocratic tendencies. They perpetrate these through a several ways which include godfathers, succession crises and abuse of incumbency, electoral malpractices, electoral violence, and political alienation, travesty of justice, recourse to primordial cleavages, corruption and inconsistent policy inconsistency, human rights abuse, to mention but some. This article is qualitative. It argues that there is need to make reform in the Electoral Act and strengthen the anti-corruption crusade in order to check the excesses of the political class and record fundamental gains in Nigeria's democratic experience.
\end{abstract}

(C) 2020 The authors, under a Creative Commons Attribution-Non Commercial 4.0

Recommended citation: Innocent, A. P., Eikojonwa, O. and Mohammed, I. I. (2020). The Political Class as a Threat to Democracy in Nigeria's Fourth Republic. Review of Politics and Public Policy in Emerging Economies, 2 (2), 111-117.

\section{Introduction}

The political class play critical roles in the establishment and consolidation of democracy. However, rather than fostering the unity that would create national integration and consolidate its democracy, Nigeria's political class engages in political actions and rivalry that weaken national unity and democratic stability. This is inherent in the operations of political parties and the antidemocratic actions of the political class. 
It is instructive to note that the three major political parties of the First Republic were regionally based. The Northern Peoples' Congress was a northern-based party and got its support from people of northern stock majorly, those who make up the north-east, north-west and the folk of people who make up north-central Nigeria today. The National Council of Nigerian Citizens, NCNC drew overwhelming support from Eastern Nigeria while the Action Group was dominated by those of Western extraction (Akubo \& Yakubu, 2014).

Deliberate attempts were made to ensure that the Second Republic's political parties did not assume the character of the banned political parties and as soon as the transition time-table of the Second Republic was made public, there was a criterion that parties must have national spread with widespread ethnic representation. This was incorporated in the fundamental objectives of the new constitutional arrangements which placed emphasis on the need for the country to encourage the formation of political associations that would have national character (Diamond, 1997).

An important feature of the structure of the cleavage could be deduced from the character of the five political parties that emerged, the parties of the first republic, the second republican parties had strong ethnic bases. The National Party of Nigeria (N.P.N) was an offshoot of the old Northern Peoples' Congress (N.P.C) with its base in the North. The Unity Party of Nigeria (U.P.N) was Action Group in disguise and had its stronghold in the Yoruba area of the West and was led by Chief Obafemi Awolowo ( Dode 2010, Innocent, Yusoff \& Rajanthiran, 2017).

The Nigerian Peoples Party (N.P.P) was a rebirth of the defunct N.C.NC with membership drawn mainly from the East under Dr Nnamdi Azikiwe.The Peoples Redemption Party (P.R.P) was an offshoot of the radical Hausa party, the Northern Elements Progressive Union (N.E.P.U) led by Mallam Aminu Kano. And even the Great Nigeria Peoples Party (G.N.P.P) under Waziri Ibrahim was stronger in his home state and could rightly be compared to the Borno Youth Movement (Diamond 1997).

The aborted Third Republic was characterised by undemocratic developments such as control of the party machinery by affluent members of the two political parties created by Babangida, the Social Democratic Party (SDP) and the National Republican Convention (NRC). As time went on, the two parties experienced both intra party and inter-party violence and factionalism and, as such, it could be said, without mincing words, that despite the massive investment made by the government, its political expectations remained largely unrealised. The two parties remained parochial, fragile and weak like their counterparts in the First and Second Republics (Oyediran \& Agbaje, 1991).

The Fourth Republic political parties have been replete with several antidemocratic tendencies which negate their ability to contribute to the deepening of democratic governance. These are perpetrated by the political elites and their cronies. Without malice to the crop of genuine patriots involved in the battle to save Nigeria from the hands of those wishing to pocket the state, political parties in the fourth republic have proven to be the most unpatriotic of the generations of political parties and classes the Nigerian state has known, their actions are counterproductive, antidemocratic, greedy and enveloped in clouts of corruption, they have demonstrated the aforementioned with godfatherism, electoral fraud, electoral violence, ethnicity, among others (TMG 2007 \& Omotola 2010). 


\section{Conceptual Review and Theoretical Framework Literature Review \\ The Political Class}

Mosca(cited in Bottomore, 1964) asserted that, two distinct classes of people exist in every society, a class that rules and a class that is ruled. The ruling class is always the less numerous, performs all political functions, monopolizes power and enjoys the advantages that power brings, while the ruled is the more numerous class but always at the capricious whims of ruling class.

Mosca maintained that the rule of the minority over the majority is such that the former is organized the dominion of an organized minority, obeying a single impulse, over the unorganized majority is inevitable. The power of any minority is irresistible as against each single individual in the majority, who stands alone before the totality of the organized minority. At the same time, the minority is organized for the very reason that it is a minority and also by the fact that the minority is usually composed of superior individuals, members of the ruling minority regularly have some attribute, real or apparent, which is apparent, which is highly esteemed and highly influential in the society in which they live (Mosca cited in Bottomore, 1964).

If democracy is truly a political organization, it may well be argued, as many have done, that it is government by the people. The significance of political democracy is primarily that the positions of power in society are open in principle to everyone, that there is competition for power, and that the holders of power at any time are accountable to the electorate. Schumpeter presented such a view of democracy, which has since been widely accepted when he defined the democratic methods as that institutional arrangement for arriving at political decisions in which individuals acquire the power to decide by means of a competitive struggle for the people's vote.

\section{Democracy}

There is no doubt that democracy implies different things to different people. However, there are certain indices upon which scholarly definitional assumptions could be based. Strictly speaking, democracy refers to a governmental arrangement in which political power is widely spread, where power to some extent resides with the people (Makinda, 1996). Democracy, therefore has a correlation with political equality(Arblaster,2002).

In a democracy, citizens are guaranteed of rights and the state ensures that excessive material and poverty as well as social and economic inequalities are forestalled. A liberal democracy could be said to have become deepened if the extent of participation, competition and fundamental liberties have been expanded (O;Donnell and Schmitter 1986; Sorensen 1998).

Schedler (1998a, 1998b) attempted to describe several usages and what democratic consolidation implies. In view of this, one of the alternatives of democratic consolidation is the deepening of liberal democracy and tilting it towards advanced democracy.

\section{Methodology}

This paper is based entirely on qualitative sources of data. These sources include relevant textbooks, journals, articles and online materials on the African politics. Conclusion will emerge from content analysis

\section{The Crux}

It is pertinent at this point to discuss the nature and character of the Nigerian ruling and governing class which constitute threats to democracy and democratic consolidation in Nigeria. These attributes are not limited to but include the following:

Godfatherism: Political parties are populated by godfathers, moneybags and ex- military leaders 
and party primaries are mere manipulations (Adeyemi, 2012). The conduct of godfathers in political parties makes the parties ineffective in the cause of performing their roles. This practice weakens democratic governance by circumscribing citizens participation in politics. In ways antithetical to democratic ethos, political class impose candidates at all levels that they surrender the state resources to them if they win the election and take over the reins of government (Omotola, 2007). This makes the gains of democracy to remain unrealistic to the electorates and threatens democratic governance (ICG, 2007b).

Succession Crises/ Abuse of incumbency: Power succession implies the transfer of political power from one group to another. The extent of orderliness with which the transfer is carried out is viewed as an indication of maturity of the state or society concerned and is accepted globally as a criterion for measuring the level at which democracy is consolidated.

What has been established that the party in power is always more involved in this act than opposition parties during elections in Nigeria (Onapajo, 2014). This is not to completely vindicate the opposition parties. For instance, the 2007 elections were obviously characterised by colossal violence (TMG, 2007).

Electoral Malpractices: More often than not, political parties, particularly the ruling ones, rely on electoral fraud instead of popularity among the electorates to assume and retain power. Elections are not only defective but perverted (Adeyemi, 2012) As a result, the political significance of parties is no longer due to popular support but through devious activities. To that extent, therefore, parties' channel massive resources to discipline members, accusing them of antiparty misdemeanour. Nigerian political parties and the political class have a plethora of tactics to exclude popular contestants from party primaries (Ibrahim, 2006).

Electoral Violence: Since the commencement of the Fourth Republic, general elections have been conducted in 1999, 2003, 2007, 2011, 2015 and 2019. These elections have been marred by some level of violence. There were cases of manipulation and killing of perceived political enemies accused of antiparty activities being perpetrated by the then ruling party, the People's Democratic Party (PDP) in its desperation to cling to power.

The 2011 general elections were assessed by several domestic and foreign observers as the most transparent poll conducted by the Independent National Electoral Commission (INEC) since the return to democracy (Agbambu\& Ajayi, 2011; EU, 2011). Nevertheless, some violence took place (EU, EOM, 2015; Gordon, 2015).

Political Alienation: Pre-election violence often create a general atmosphere of fear in the electorates and reduces the rate of voter turnout during the general elections (Bratton, 2008). This affects the results of the elections (Igbuzor, 2010). While the acts of violence by the incumbents provoke reprisals by the opposition elements, the connivance of the incumbents with security agencies give them an edge in suppressing the opposition and its supporters (EU, EOM, 2007). The incumbents often perceive the state as a political heritage that must be forcefully captured using the state apparatus and instruments of coercion to crush any opponent.

Travesty of Justice. Ideally, the judiciary is adjudged to be the last hope of the common man. When politicians feel short changed in the electoral contest, they seek justice in tribunals and courts. Courts have been used to redeem election mandates in Nigeria's Fourth Republic (Unobe, 1990, Omotola, 2010). However, the political class have formed the habit of getting court orders, even when they know the cases are not plausible. These baseless litigation struggles constitute 
roadblocks to the electoral process. This has brought the judiciary to unsavoury reputation in the Fourth Republic, posing abysmal threat to democracy.

Recourse to Primordial Cleavages: In the Fourth Republic, the political class, like their predecessors always resort to primordial sentiment to pitch the citizens against one another and overheat the polity (Omotola 2010, Innocent, Yusoff \& Rajanthiran, 2017). The introduction of Sharia in the early years of the Fourth Republic sparked a lot of violence in some northern states and reprisals in the south. Occasionally, especially during electioneering campaigns and build up to elections, politicians, especially in states that are have different ethnic groups and religious affinities, appeal to ethnic and religious considerations for political support and allegiance (Jinadu, 2011).

Corrupt Practices: Since independence, remains an agonizing thorn in the flesh of the country's democratic progress and development and the Fourth Republic is not an exception. Political and public officers have made corruption a hobby and this has posed gross nuisance to the country's beleaguered democracy. Abundant evidence abounds in corruption cases involving high profile personalities, some of whom have even been convicted. For instance, former Governors Jolly Nyame of Taraba State and Joshua Dariye of Plateau State are serving various jail terms for allegedly misappropriating billions of naira meant for their states. Others having corruption charges are former National Security Adviser, Sambo Dasuki, a former Petroleum minister, Deziani Madueke to mention a few. These acts of corruption is not limited to politicians alone, but they do it in connivance with public officers or civil servants to milk the nation dry, retard its development and truncate its democratic governance.

Policy Inconsistency: Inconsistency in policy formulation and implementation mitigates democratic growth in Nigeria's Fourth Republic. Successive regimes always abandon infrastructural projects and programs of their predecessors (Egwu, 2015, Elaigwu, 2014).

Human Rights Abuse: Fundamental human rights and citizens liberty is one of the essential hallmarks of democracy (Rudra, 2005; Omotola, 2015). However, the political class infringe on the fundamental rights of citizens. The narrow-mindedness of the political class to criticisms is manifested by their current quest to enact and pass social media bill to enable them truncate criticisms generated by their colossal misrule (Okolo, 2014).

\section{Conclusion}

It is a universal notion that democracy is the form of government that offers the citizens the opportunity to actualize their goals. Sadly, this has remained largely nominal in the country. The contributions of Nigeria's political class to the growth of its democratic governance have remained at a lowest ebb. They contribute to democratic deceleration rather than democratic consolidation.

In order to redress the ugly scenario painted above, there is need for the government to sign the Electoral Act into law and restore credibility in all facets of the electoral process. The rule of law and due process must be adhered in both the political and public administration. Citizens liberty must be observed, irrespective of their political leaning, ethnic background or religious leaning. There should be stakeholder's participation in policy formulation and implementation. The anticorruption fight of the current government should be all-encompassing to avoid allegations of unevenness and political prejudice. Efficient citizenship education should be carried out to educate citizens of their rights in a democratic society to enable them hold leaders accountable for their actions. These suggestions could forestall the challenges besetting Nigerian democracy. 


\section{References}

Agbambu, C. and Ajayi, A. (2011), 'US Rates Nigeria's ElectionsHigh, Says Country Made History with April Polls...' NigerianTribune (Ibadan), 29 April.

Akubo, A A and Yakubu, A U (2014) Political Parties and Democratic Consolidation in Nigeria's Fourth Republic. Global Journal of Political Science and Administration Vol 2, No 3, pp 79-108.

Arblaster, A (2002) Democracy. Milton Keynes: Open University Press.

Bottomore, T.B (1964) Elites and Society. Penguin Books, Baltimore, Maryland.

Bratton, M (2008), Vote Buying and Violence in Nigerian Election Campaigns, in: Electoral Studies, 27, 621-632

Diamond, L (1997) Consolidating the Third Wave Democracies, Baltimore, MD: Johns Hopkins University Press.

Diaspora 2(2).

Dode, O.R (2010) Political Parties and the Prospects of Democratic Consolidation in Nigeria: 1999-2006. Africa Journal of Political Science and International Relations, Vol. 4 (5) pp 188-194.

Egwu, S.G. (2015, September 8). Nigeria's 2015 general election: Outlook and challenges. West Africa Insight, Retrieved from: http://westafricainsight.org/articles/view/299

Elaigwu, J. I. (2014). Democracy and Democratic Deficits. In J. I. Elaigwu (Ed.), Federalism and Democracy in Nigeria: Fifty Years After. Jos: Institute of Governance and Social S.G. (2015, September 8). Nigeria's 2015 general election: Outlook and challenges.

WestAfrica Insight, Retrieved from: http://westafricainsight.org/articles/view/299

EU EOM (2011), EU Observation Mission to Nigeria: Final Report onthe 2011 General Elections: Abuja: European Union.

European Union Election Observation Mission (2015). Final Reporton General

Elections 28 March and 11 April 2015. Fourth Republic, 1999-2007'. Africana: A Journal of Ideas on Africa and the African

Gordon, M. (2015), Kerry Meets with Nigerian Leaders toEncourage Peaceful Election, The New York Times, January 25.

Ibrahim, J (2006), Nigeria's 2007 Elections: A Fitful Path to Democratic Citizenship, Washington, D.C.: United States

Igbuzor, O. (2010). Electoral violence in Nigeria. Asaba, Action AidNigeria.

Innocent,A.P Yusoff, K.Z, Rajanthiran, S.P (2017) Political Parties and the Quest for Democratic Sustenance in Nigeria's Fourth Republic. International Journal of Public Administration and Management, Vol. 4(1) 58-63.

International Crisis Group (ICG) (2007), Nigeria: Failed Elections, Failing State?, Africa Report, 126, 30 May, online: <www.crisisgroup.

Makinda, S.M (1996) Democracy and Multiparty Politics in Africa, Journal of Modern African Studies, Vo 34 (4) pp555-573.

O' Donnell, G and Schmitter, P.C (2000) The Dynamics of Democratization: A Comparative Approach. London. Continuum. pp 20-24.

Okolo, B.S. (2014). Survival of the Nigerian state. African Security Review, 23 (2), 161-171

Omotola, J S. 2007a. 'Democracy and Constitutionalism in Nigeria Under the

Omotola, S (2007b) Godfathers and the 2007 Nigeria's Elections. Journal of African Elections,134-154.

Omotola, S (2010), Explaining Electoral Violence in Africa's Democracies, in: African journal on Conflict Resolution, 10, 3, 51-73.

Oyediran, O \&Agbaje, A.A.B(1999) 'Introduction'. In O Oyediran\& A A B Agbaje Press.

Sorensen, G (1993), Democracy and Democratisation Boulder, Colo.: Westview Press 
Transition Monitoring Group (TMG) (2007), An Election Programmed Fail: Final Report of the April 2007 General Elections in Nigeria, TMG, online: $<$ http://tmgng.org/resources/publications> (20 2011).

Unobe, E. A. 1990. 'Partisan Judiciary and Political Instability in Nigeria'. In I E SNigeria. Zaria: Nigerian Political Science Association 